\title{
SHOCKS AND SHOCK ABSORBERS: THE INTERNATIONAL PROPAGATION OF EQUITY MARKET SHOCKS AND THE DESIGN OF APPROPRIATE POLICY RESPONSES ${ }^{1}$
}

\author{
Ray Barrell ${ }^{2}$ \\ NIESR \\ 2 Dean Trench Street \\ Smith Square \\ LONDON SW1P 3HE \\ and \\ E Philip Davis ${ }^{3}$ \\ Brunel University \\ Uxbridge \\ MIDDLESEX UB8 3PH
}

30th June 2005

\begin{abstract}
Equity prices are major sources of shocks to the world economy and channels for propagation of these shocks. We seek to calibrate macroeconomic effects of falls in share prices and assess appropriate policy responses, using the National Institute Global Econometric Model NiGEM. Based on estimated relationships, falls in US equity prices have significant impacts on global activity; potential for liquidity traps suggest a need for complementary monetary and fiscal policy easing. However, fiscal easing boosts long-term real interest rates and hence moderates one of the automatic shock absorbers provided by the market mechanism.
\end{abstract}

JEL Classification: E17, E27, E63

Keywords: Financial markets and the macroeconomy, Stabilization policy, Macroeconomic modelling

\footnotetext{
${ }^{1}$ This research has been supported by the ESRC under grant number L138250122. The authors thank Stephen Davies and participants in seminars at NIESR and the Bank of Canada for helpful comments.

2 Senior Research Fellow, NIESR and Visiting Professor, Imperial College. Corresponding Author. e-mail, rbarrell@niesr.ac.uk, tel (44) 2072227665

3 Professor of Economics and Finance, Brunel University and Visiting Fellow, NIESR. e- mails: philip.davis@brunel.ac.uk and e_philip_davis@msn.com
} 


\section{Introduction}

Equity prices and equity markets are major sources of shocks to the world economy and major channels for the propagation of these shocks. In this paper we seek to calibrate their effects, and assess what policy responses can best absorb them. We first briefly discuss the evidence for the effects of equity prices on real economic activity and look at some evidence on the relationship between equity prices and output using Vector Error Correction (VECM) Models. We compare these results for the US and the major Euro Area countries to those produced using the National Institute Global Econometric Model NiGEM. We assess the implications of equity price falls comparable to those seen in 2000-2 in the context of NiGEM, presenting a range of simulations on the model. These give a view of the macroeconomic impact of equity market falls, viewed in the context of the high degree of correlation between equity price changes in the recent past, and also give an indication of the effect of differing policy responses.

\section{The Macroeconomic Importance of Equity Markets}

There is a significant literature investigating the impact of wealth - itself driven partly by share prices - on consumption. Davis and Palumbo's (2001) study of the US consumption function attempts to determine whether changes in wealth affect the growth rate of consumer spending. They examined quarterly aggregate US data from 1960 to 2000 and modelled long-

run relationships to investigate whether (logged) consumption, income and wealth share a common trend. They found that there is a statistically significant long run wealth effect on consumer spending. Ludvigsen and Steindel (1999) also examined wealth effects in a loglinear long-run consumption relationship and found a statistically significant wealth and income effect. They also showed that these variables share a common trend, using quarterly US data, as do Lettau and Ludvigsen (2001).

Barrell and Davis (2004a) look at a similar standard model of consumption for the G5 economies. Income and wealth effects are significant, and there is a clear role for both the level and the change in financial wealth. However, they also find that wealth effects differ between countries, with no impact from changes in equity-based wealth in Germany but a relatively strong effect in the US. Complementing this, Byrne and Davis (2003a) investigated the impact of disaggregated financial wealth on consumption for G-7 countries, and found that, contrary to earlier empirical work, illiquid financial wealth, (equities, bonds, life insurance and pension assets less mortgage debt) scaled by personal disposable income (PDI), tends to be a more significant long-run determinant of consumption than liquid financial wealth (deposits and money market instruments less other debt) across the G-7. Again, the 
effect varied across countries. They suggested that the overall pattern reflects a shift from liquidity constrained to life cycle behaviour following financial liberalisation, and also a more disaggregated pattern of wealth holding. Barrell and Davis (2004b) indeed found that financial liberalisation is accompanied by a rise in wealth effects and fall in income effects consistent with elimination of liquidity constraints.

The differences in response of consumption to wealth found in these papers reflects the relative importance of both direct and indirect holding of equities in household portfolios. Table 1 shows the ratio of wealth to personal disposable income (PDI) in the major economies. As regards changes in wealth which could impact on consumption, the table shows that falls in the UK and US over 1999-2001 were 100\% of PDI, and are likely to have been much greater by end-2002. Falls in France and Italy were around half those in the UK and US, while the data showed relatively small declines in Germany, Canada and Japan. The penultimate line shows direct equity holdings ${ }^{4}$, while the bottom line, from Byrne and Davis (2003b), makes a correction for institutional holdings on behalf of households. It shows that portfolio shares of equity allowing for indirect holdings are quite comparable across the G-7, with the outliers being Japan and to a lesser extent Germany and Italy. The ratio of direct to total equity holdings is an indicator of the immediate visibility of equity price changes to consumers, and might be expected to affect the speed of response to a change in equity prices.

Table 1: Household wealth-income ratios

\begin{tabular}{|c|c|c|c|c|c|c|c|}
\hline \multicolumn{7}{|c|}{ Net financial wealth/personal disposable income ratio } \\
\hline & UK & US & Germany & Japan & Canada & France & Italy \\
\hline 1998 & 3.78 & 2.56 & 1.63 & 3.02 & 2.40 & 2.66 & 2.66 \\
\hline 1999 & 4.02 & 2.73 & 1.58 & 3.23 & 2.48 & 2.92 & 2.75 \\
\hline 2000 & 4.03 & 2.93 & 1.73 & 3.42 & 2.44 & 3.03 & 2.89 \\
\hline 2001 & 3.38 & 3.02 & 1.54 & 3.49 & 2.38 & 2.63 & 2.68 \\
\hline 2002 & 2.95 & 3.36 & 1.65 & 3.50 & 2.32 & 2.52 & 2.41 \\
\hline 2003 & 2.81 & 3.70 & & 3.33 & 2.49 & 2.63 & \\
\hline \multicolumn{7}{|c|}{ Memo: Personal sector direct equity holdings/personal disposable income ratio } \\
\hline 2001 & 0.59 & 0.85 & 0.36 & 0.34 & 0.99 & 1.08 & 0.62 \\
\hline
\end{tabular}

Source: National flow-of-funds balance sheet data, Datastream

Turning to investment, as shown in IMF (2003), declines in investment often have a substantial impact on GDP growth after equity price falls, and falls in investment were sizeable in the recent bear market, partly linked to the high level of corporate debt and reliance on external finance generally in the bull period. The potential channels of

\footnotetext{
${ }^{4}$ Note from the memo line that the direct holdings of equity are largest in France, Canada and the US and lowest in Germany and Japan. The large difference between this figure and illiquid financial wealth is largely a consequence of the importance of institutional investors, albeit also in some countries reflecting bond holdings.
} 
transmission ${ }^{5}$ include Tobin's Q (the valuation of firms relative to the replacement cost of the capital stock) and the financial accelerator, (whereby the level of corporate net worth eases concerns of lenders over moral hazard, and hence external finance constraints). Evidence for the US suggests that the stock market bubble of the late 1990s influenced corporate investment, raising it significantly (Gilchrist, Himmelberg and Huberman, 2004). More generally there is a significant body of evidence for the US that stock prices affect the level of investment and hence have an impact on the level and rate of change in GDP, although other factors such as the existence of external finance constraints over and above those shown by the financial accelerator, appear to explain investment behaviour as well (Hubbard 1998).

Firms in the US are generally more dependent on equity markets for their finance than are firms in the Euro Area, where the strength of links with banks should reduce the importance of financial constraints and equity prices on investment. Bank finance has historically been important in Italy, France and Germany. We would in general expect more market-based economies to have more impact from equity prices and from external finance constraints, and this does appear to be the case. For instance Bond et al (2003) construct a set of company panel data for Belgium, France, Germany and the UK over the period 1978 to 1989 and find that financial constraints and the associated variations in market based equity risk premia were perhaps more important in the UK, which is more similar to the US in terms of the structure on investment finance than are the members of the Euro Area.

The differences in financial structure that we discuss above impact on the reactions of economies to equity market shocks, and influence the differences between countries that we observe in the Monetary Transmission Mechanism. The traditional money based view of this mechanism is that interest rates affect consumption and investment in perfect capital markets, and induce substitution over time. Imperfect capital markets and the existence of liquidity constraints are at the core of the credit view of the transmission mechanism, in the spirit of the pattern of wealth effects and the financial accelerator and these can at least partly be picked up by investigating the role of equity prices in the overall economy. Allen, Chui and Maddeloni (2004) discuss the impacts of financial systems in Europe and the US on the transmission mechanism, stressing the role of bank versus market based systems as well as the importance of equity markets.

The impacts of equity prices on GDP can be evaluated either with Vector Autoregressive (VAR) based models or with more structural approaches. Pesaran et al (2004) build a compact Vector Error Correction (VECM) based global model of 25 linked countries in which they

\footnotetext{
${ }^{5}$ See Ashworth and Davis (2001).
} 
focus on domestic equity price effects on GDP, showing that they are both significant and vary across countries. Pesaran et al (2005) build on this model to evaluate credit risk using this large dynamic global macroeconomic VAR model attached to descriptions of portfolios. They apply generalised impulse response functions ${ }^{6}$ for equity price shocks, calculating the correlations between past shocks and applying sets of shocks to all equity prices. Barrell and Davis (2005) use a set of VECM models model to evaluate the impacts of changes in equity prices on the economy in the EU and US, and draw a distinction between effects in bank based and market based economies. The strength of impact of equity price shocks in the US is emphasised in all these results.

\section{Estimation of Cointegrating Relationships}

As a counterpart to work with the Institute macromodel NiGEM in this paper, we first follow Barrell and Davis (2005) and seek to extend the work of Pesaran and others by further assessing links of equity prices to the real economy by estimating VECMs for the large EMU countries and the US. These have the advantage of a reduced form approach, not imposing restrictions on the data, while also allowing both short and long run (cointegrating) effects to be discerned. In each case we estimate a 4 variable VAR system, and we look for factors that would cause output to cycle around its equilibrium value. As we are investigating real output we would like to use other real variables unless there is a strong case for not doing so. We presume that we should look for policy variables and for an exogenous shock variable such as equity prices. Hence besides real equity prices (LREQP) we utilise real GDP (LY), the government surplus to GDP ratio (GBR) as an indicator of the stance of fiscal policy, and the 3-month real short rate (RR) as an indicator of the stance of monetary policy. In order to be sure that we may find a cointegrating vector, we use the data period 1971-2003, covering the era since the end of Bretton Woods, including several cycles.

As at least two of our variables, (LY and LREQP) are integrated of order one we should work in error correction form to avoid spurious regressions. We may write this as

$\Delta y=\Sigma_{i} \beta_{i} \Delta y(-i)+\gamma y(-1)+\varepsilon$

Where $\beta_{\mathrm{i}}$ is a matrix of dynamic response coefficients, $\gamma$ is the matrix of coefficients on the long run levels terms and $\mathrm{y}$ is the vector of the four explanatory variables in each country. Using standard tests we find that the length of lag in the VAR we should use does not exceed 2 quarters, and the trace and eigenvalue tests show us that there is one cointegrating vector in each country. Following Johansen (1995), we then estimate these, and place them in the VAR.

\footnotetext{
${ }^{6}$ This requires calculating the correlation between innovations across countries, and applying a shock with its
} 
We normalise on one variable in order to aid interpretation of this vector and then analyse variance decompositions.

Table 2 Estimation results - cointegrating vector 1971:1-2003:4

\begin{tabular}{|c|c|c|c|c|c|}
\hline $\begin{array}{c}\text { Normalised on } \\
\text { log real equity } \\
\text { prices }\end{array}$ & France & Germany & Nether-lands & Italy & US \\
\hline LREQP(-1) & 1.0 & 1.0 & 1.0 & 1.0 & 1.0 \\
\hline LY(-1) & -3.5 & -2.1 & -1.9 & -4.0 & -1.5 \\
\hline GBR(-1) & $(2.1)$ & $(10.1)$ & $(5.7)$ & $(2.5)$ & $(6.3)$ \\
\hline & 0.8 & -0.31 & -0.06 & -0.08 & -0.13 \\
\hline RR(-1) & 0.6 & 0.11 & 0.04 & -0.12 & 0.02 \\
\hline & $(5.7)$ & $(3.6)$ & $(1.4)$ & $(1.4)$ & $(0.7)$ \\
\hline C & 19.3 & 11.9 & 21.7 & 22.3 & 13.7 \\
\hline $\begin{array}{c}\text { Cointegration } \\
\text { specification }\end{array}$ & 3 & 3 & 2 & 2 & 2 \\
\hline Period & $1971-2003$ & $1971-2003$ & $1971-2003$ & $1971-2003$ & $1971-2003$ \\
\hline
\end{tabular}

Key to cointegration specifications: specification 2 is intercept in CE and no intercept in VAR and specification 3 is intercept in CE and VAR.

The normalised cointegrating vectors above show a much closer relationship between equity prices and GDP in the market-based US than in the five mainly bank-based Euro Area economies reported in the table. Real interest rates have the expected negative relationship with both equity prices and output in all countries except Italy, whilst the sign of the impact of improvements in the fiscal position (the level of public borrowing as a percent of GDP) is negative in three countries and positive in three, suggesting that the direction of causation between borrowing and output is not at all clear ${ }^{7}$.

Table 3 Selected variance decompositions of LREQP and LY after 20 quarters

\begin{tabular}{|c|c|c|c|c|c|}
\hline Decomp of..by & France & Germany & Netherlands & Italy & US \\
\hline LREQP & 96 & 94 & 72 & 95 & 93 \\
\hline LY & 3 & 1 & 1 & 2 & 5 \\
\hline GBR & 0 & 5 & 26 & 2 & 1 \\
\hline RR & 1 & 0 & 0 & 0 & 1 \\
\hline & & & & & \\
\hline LY & 87 & 87 & 76 & 49 & 22 \\
\hline LREQP & 12 & 4 & 22 & 32 & 51 \\
\hline GBR & 2 & 6 & 1 & 1 & 26 \\
\hline RR & 0 & 2 & 0 & 18 & 0 \\
\hline
\end{tabular}

Examination of estimation results gives some information, but for our purposes the main outputs of interest from a VECM are variance decompositions. As a first step we use the decomposition of the variances of 20 step ahead forecasts by components of the error correction equation to evaluate the structure of the economies we are studying. As shown in Table 3, we may note in particular the "autonomy" of share prices in variance 
decompositions, compared with a marked (albeit variable) impact of share price variance on real GDP. In the variance decomposition for equity prices the extremes are France and the Netherlands, with the forecast variance for most share prices being explained solely by the past history of equity prices themselves. Most economies in our sample have virtually autonomous equity markets

The variance decompositions for output are much more varied, with past history for output contributing between 34 and 87 per cent, with equity prices contributing between 4 and 51 per cent. The largest role for equity prices in the decomposition of output variance is in the US, with a share above 50 per cent. The large share for the US does fit with our priors and there is clearly a strong case to be made for there being a difference between this large equity based economy and the others.

We argue that changes in US equity prices impact directly on the European economies through direct holdings of US equities in European portfolios and as US share price movements lead other markets. As a variant, we included real US share prices in the VECM for the larger EU countries. We reran the tests for these EU countries with the log of real US share prices coming first in the Choleski ordering. As can be seen from the variance decomposition, there is a major impact of including the US on share price variance indicating a considerable influence of the US on EU markets - but no change to the overall autonomy of share prices. US equity prices seem to be relatively important in the very open equity market in the Netherlands. As regards the determination of domestic output, there is now a large contribution by US share prices, with it being more important in the decomposition than domestic equity prices in all economies except for Germany. The overall impact of share prices is comparable to the basic results.

Table 4 Selected variance decompositions of LREQP and LY after 20 quarters including US share prices (percent)

\begin{tabular}{|c|c|c|c|c|}
\hline Decomp of..by & France & Germany & Netherlands & Italy \\
\hline LREQP & 60 & 57 & 29 & 54 \\
\hline USLREQP & 37 & 39 & 48 & 43 \\
\hline LY & 1 & 0 & 1 & 1 \\
\hline GBR & 0 & 3 & 22 & 1 \\
\hline RR & 1 & 0 & 0 & 0 \\
\hline & & & & \\
\hline LY & 82 & 61 & 76 & 68 \\
\hline USLREQP & 13 & 1 & 18 & 14 \\
\hline LREQP & 3 & 8 & 3 & 9 \\
\hline GBR & 2 & 12 & 2 & 5 \\
\hline RR & 0 & 19 & 0 & 5 \\
\hline
\end{tabular}

\footnotetext{
${ }^{7}$ Barrell and Davis (2005) suggest that in most countries there is evidence of an association between large deficits and low GDP, indicating expansionary fiscal contractions are possible.
} 


\section{$3 \quad$ Modelling the Impact of Equity Prices}

Over the last 18 years, NIESR has developed the global macro model NiGEM for use in policy analysis ${ }^{8}$. NiGEM is an estimated model, which uses a 'New-Keynesian' framework in that agents are presumed to be forward-looking, but nominal rigidities slow the process of adjustment to external events. All countries in the OECD are modelled separately. All economies are linked through the effects of trade and competitiveness. There are also links between countries in their financial markets via the structure and composition of wealth, emphasising the role and origin of foreign assets and liabilities. There are forward-looking wages and exchange rates, while long-term interest rates are the forward convolution of shortterm interest rates. The model has complete demand and supply sides and there is an extensive monetary and financial sector. NiGEM contains expectations and uses the Extended Path Method to obtain values for the future and current expectations and iterate along solution paths

International propagation of shocks to US equity prices in the model relies on two main sets of channels. Those due to model structure, notably trade and the effects of financial asset valuations on consumption, propagate the shock through US demand for foreign output or through the impact on the demand of foreign residents for all output. We detail aspects of the underlying equations below. In addition, policy responses can be part of the propagation of the shock. If both demand and inflation in the US fall then the Federal Reserve can be expected to cut short-term interest rates. This will help to absorb the shock, but it will also cause the dollar to fall. The depreciation of the dollar improves US competitiveness and also helps to absorb the shock in the US. It will raise US exports and reduce imports as compared to where they would otherwise have been without the improvement in competitiveness. The improvement in competitiveness must be matched elsewhere by deterioration in other countries' competitiveness, and this also propagates the shock to other countries.

Shocks are not only absorbed by the operation of policy rules, but also by the market mechanism. If policy reduces short term interest rates, and is expected to continue to do so, then this causes the long term interest rate to fall, inducing a rise in bond prices that should partly offset the impact on wealth of the fall in equity prices ${ }^{9}$. A decline in US consumption driven by a fall in equity prices and hence wealth raises US saving. The long term real interest rate in our model, which drives the user cost of capital, will fall in the US and elsewhere as a

\footnotetext{
${ }^{8}$ See Barrell, et al (2004) for a brief description.

${ }^{9}$ Bond prices depend on the long rate on bonds, and revaluations change with the level of the rate. Japanese long rates have been much lower than elsewhere for some time, and hence revaluations differ in that country.
} 
result of changes in the saving and investment balance. This gives a potential boost to investment both in the US and elsewhere, and reduces the impact of a rise in the risk premium.

\subsection{The Structure of NiGEM}

Trade in Goods and Services. These equations depend upon demand and relative competitiveness effects, and the latter are defined in similar ways across countries. It is assumed that exporters compete against others who export $(\mathrm{X})$ to the same market via relative prices (RPX), and demand is given by the imports in the markets to which the country has previously exported (S)

$\Delta \ln \mathrm{X}=\lambda[\ln \mathrm{X}(-1)-\ln \mathrm{S}(-1)+\mathrm{b} * \ln \mathrm{RPX}]+\mathrm{c} 1 * \Delta \ln \mathrm{X}(-1)+\mathrm{c} 2 * \Delta \ln \mathrm{S}+$ error

while imports (M) depend upon import prices relative to domestic prices (RPM) and on demand (TFE)

$\Delta \operatorname{lnM}=\lambda[\ln \mathrm{M}(-1)-\mathrm{b} 1 * \ln T F E(-1)+\mathrm{b} 2 * \ln R P M]+\mathrm{c} 1 * \Delta \ln \mathrm{M}(-1)+\mathrm{c} 2 * \Delta \ln \mathrm{TFE}+\mathrm{error}$

As exports depend on imports, they will rise together in the model. Of particular relevance for this paper, we can be certain that if US imports fall that will be reflected in declines in exports elsewhere in the world.

Financial markets Forward looking nominal long rates LR and long real rates have to look T periods forward using expected short-term nominal and real interest rates respectively using

$\left(1+\mathrm{LR}_{\mathrm{t}}\right)=\prod_{\mathrm{j}=1, \mathrm{~T}}\left(1+\mathrm{SR}_{\mathrm{t}+\mathrm{j}}\right)^{1 / \mathrm{T}}$

Forward looking exchange rates RX have to look one period forward along the arbitrage relation involving domestic and foreign short term interest rates (SRH and SRF)

$\mathrm{RX}_{\mathrm{t}}=\mathrm{RX}_{\mathrm{t}+1}\left(1+\mathrm{SRH}_{\mathrm{t}}\right) /\left(1+\mathrm{SRF}_{\mathrm{t}}\right)$

Forward looking equity prices are solved out from the discounted sum of expected discounted profits (П), divided by the real stock of capital $(\mathrm{K})$. The discount factor is made up of the nominal interest rate, $r$, and the risk premium on equity holding decisions, $r p e$.

$E Q P_{t}=\Sigma_{i=1}^{\infty}\left(\left(\prod_{t+i} / K_{t+i}\right) /((1+r)(1+r p e))\right)$

This can be written as an infinite forward recursion that depends only on current profits and the expected equity price next period, which embeds information on future profits.

$\mathrm{EQP}_{\mathrm{t}}=\prod_{\mathrm{t}}+\mathrm{EQP}_{\mathrm{t}+1} /(1+r)(1+r p e)$ 
The equity price will jump when any of its future determinants changes, and the risk premium is set at its recent value unless reset in the experiment, as it is here.

Wealth and asset accumulation. The wealth and accumulation system allows for flows of saving onto wealth and for revaluations of existing stocks of assets in line with their prices determined as above. In the medium term, personal sector liabilities are assumed to rise in line with nominal personal incomes, and if there are no revaluations, gross financial wealth will increase by the nominal value of net private sector saving plus the net increase in nominal liabilities. Revaluations come from three sources, as follows:

(1) Domestic Equity Prices. These revalue the proportion of the domestic share of the portfolio that is held in equities, both quoted and unquoted. We assume that unquoted shares rise in line with quoted shares. Balance of Payments data include an estimate of the equity stock of the domestic production sector held abroad.

(2) Domestic Bond Prices The scope of revaluations to bonds is calculated using information on the maturity structure of government debt. When long rates jump down bond prices jump up. Data are available on the proportion of debt held abroad, and this is used in revaluations.

(3) Foreign Assets and Liabilities There is information on the structure of liabilities to foreigners, and hence when equity and bond prices change, the value of Gross Liabilities also changes. Countries receive revaluations in proportion to their stock of Gross Assets as a share of the world total after factoring out banking sector deposit assets. Hence a change in US (and other) equity prices affects Gross Assets and hence wealth in other countries 'correctly', as do changes in the value of bonds held abroad.

Cross-country differences in the importance of assets as a percent of income, and in the structure of assets, as well as the responsiveness of consumption to them are important factors driving the following results:

Consumption and Personal Income. The consumption (C) relations are based on Barrell and Davis (2004a), with a role for real net financial wealth (RNW) and real personal disposable income (RPDI), as well as for housing wealth and house prices where appropriate. Dynamic terms in real wealth and real income are included as appropriate. Although in the long run real wealth effects are similar everywhere, as Barrell and Davis (2004a) stress, they are absent in the dynamics in Germany, for instance, and important in the dynamics of adjustment in the US. The resulting equation with all variables in logs is;

$\Delta \operatorname{lnC}=\lambda\left[\operatorname{lnC}(-1)-a^{*} \ln R P D I(-1)-(1-a) * \operatorname{lnRNW}(-1)\right]+b_{1} \Delta \operatorname{lnC}(-1)+b_{2} \Delta \ln R P D I+b_{3} \Delta \ln R N W$ 
As outlined above, it is assumed that besides being cumulated saving, wealth is affected by financial market activity through equity and bond prices, and if these markets 'expect' something in the future then it will be reflected in prices. News that changes expectations will cause wealth to be revalued, and hence will affect behaviour now. Published data on Net Financial Wealth ${ }^{10}$ are used, and the ratios of wealth to income and of wealth to consumption will influence the properties of the model.

Production. For each country there is an underlying CES production function which constitutes the theoretical background for the specification of the factor demand equations for employment and the capital stock, and which form the basis for unit total costs and the measure of capacity utilisation which then feed into the price system. A CES production function that embodies labour augmenting technological progress (denoted $\lambda$ ) with constant returns to scale can be written as:

$Q=\gamma\left[s(K)^{-\rho}+(1-s)\left(L e^{\lambda t}\right)^{-\rho}\right]^{-1 / \rho}$

$\gamma$ and $s$ are production function scale parameters, and the elasticity of substitution, $\sigma$, is given by $1 /(1+\rho)$. Variables $K$ and $L$ denote the net capital stock and labour input measured in terms of employee hours. In general we find that the elasticity of substitution is around a half. The parameters of the production function vary across countries and $w, c$ and $p$ denote respectively labour costs per head, nominal user costs of capital and the price of value added (at factor cost) and $\beta$ denotes the mark-up. With long-run constant returns to scale, we obtain log-linear factor demand equations of the form:

$$
\begin{aligned}
& \operatorname{Ln}(L)=[\sigma \ln \{\beta(1-s)\}-(1-\sigma) \ln (\gamma)]+\ln (Q)-(1-\sigma) \lambda t-\sigma \ln (w / p) \\
& \operatorname{Ln}(K)=[\sigma \ln (\beta s)-(1-\sigma) \ln (\gamma)]+\ln (Q)-\sigma \ln \left(c / p^{*}(1+r p)\right)
\end{aligned}
$$

These long run factor demands are embedded in error correction models, with adjustment to equilibrium after a shock taking place more quickly in the US than in the Euro Area countries. The speed of adjustment can also depend upon Tobin's Q, here measured as the ratio of the value of the equity market to the current value of the private business sector capital stock. The influence of Q on the speed of adjustment in the US is statistically important, as we would expect, but we have not found a role for it in the Euro Area countries. The long run parameters are used in the construction of an indicator of capacity utilisation, which affects the mark-up of prices over unit total costs. The capital stock adjustment equation depends upon the long run equilibrium capital stock, and the user cost of capital is influenced by the

${ }^{10}$ Data for the G7 are discussed in Byrne and Davis (2003b), and are generally available, for instance in OECD 
forward-looking real long-term rate, as well as by taxes and by depreciation. The speed of adjustment to equilibrium in the investment/capital stock adjustment equations also depends upon the short-term real interest rate, with this effect being similar across countries.

Labour markets and prices. It is assumed that employers have the power to manage, and hence the bargain in the labour market is over the real wage. In the long run, wages rise in line with productivity, all else equal. Given the determinants of the trajectory for real wages, if unemployment rises then real wages fall relative to trend, and conversely. The equations were estimated in an Equilibrium Correction format with dynamics estimated around the long run. Both the determinants of equilibrium and the dynamics of adjustment can change over time and adjustment, especially in Europe, is slow. We assume that labour markets embody rational expectations over the inflation rate and we assume that wage bargainers use model consistent expectations, either for the immediate period ahead or over a longer-term horizon. These compensation equations are discussed at some length in Barrell and Dury (2003) and all these equations are dynamically homogenous. Price equations are a profit related mark up over total costs, with speeds of adjustment reflecting data, and these are much lower in the Euro Area than in the US. In general these equations are dynamically homogenous, and if target inflation rises it will have no significant effect on the level of output.

\subsection{Policy rules}

Fiscal and monetary policy rules are important in 'closing the model' and the rules are discussed at greater length in Barrell and Dury (2000). We use simple rules that are designed to reflect policy frameworks rather than optimal rules.

Fiscal Policy rules Budget deficits are kept within bounds in the longer term, and taxes rise to do this. This simple feedback rule is important in ensuring the long run stability of the model. Without a solvency rule (or a no Ponzi games assumption) there is no necessary solution to a forward-looking model. The simple fiscal rule can be described as

$$
\operatorname{Tax}_{\mathrm{t}}=\operatorname{Tax}_{\mathrm{t}-1}+\phi[\mathrm{GBRT}-\mathrm{GBR}]
$$

Where Tax is the direct tax rate, GBR and GBRT are the government surplus target and actual surplus, $\phi$ is the feedback parameter, which is designed to remove an excess deficit in less that five years. We relax GBRT for 5 years in one of our experiments, allowing government debt as a per cent of GDP to increase to a new, higher equilibrium level

Monetary Policy Rules It is assumed that the monetary authorities adopt simple targeting rules that stabilise the price level or the inflation rate in the long term. If we use different rules in

sources. For some small countries we have constructed data in consultation with the Central Bank. 
different countries then some of the difference we observe would depend on that policy choice and in this paper we initially use the same rule for all countries. The European Central Bank (ECB) has been set the objective of maintaining price stability in the medium term. It has set itself a target for inflation within the constraints of a nominal target for the stock of money, and it describes this as the two-pillar strategy ${ }^{11}$. A combined policy of nominal aggregate and inflation rate targeting would give:

$r_{t}=\gamma_{1}\left(P_{t} Y_{t}-P *{ }_{t} Y_{t}^{*}\right)+\gamma_{2}\left(\Delta P_{t+j}-\Delta P_{t+j} *\right)$

The combined rule is chosen as the default monetary policy rule because it represents the mixed framework that is used in Europe by the ECB. We choose to use it elsewhere as the proportional controller on inflation dominates responses. Note that a fiscal expansion in the model leads to inflation via changes in the saving/investment balance - given the monetary policy rule, this will drive up short rates and hence long rates. We also report experiment where we utilise the 'industry standard' Taylor Rule where interest rates respond to the difference between actual and target inflation as well as to the output gap, which is the difference between actual and trend output.

$r_{t}=\gamma_{0}+\gamma_{1}\left(Y_{t}-\right.$ YTREND $\left._{t} *\right)+\gamma_{2}\left(\Delta P_{t+j}-\Delta P_{t+j} *\right)$

The coefficients are set at industry standard levels, with $\gamma_{1}=0.5$ and $\gamma_{2}=1.5$, whilst the intercept is endogenous, taking the value of the steady rate long term interest rate.

\subsection{Model residuals for equity prices, consumption and income}

In assessing the behaviour of the global economy during the bear market using the model, it is important to evaluate the cross-country correlation of unexplained components of key variables, which indicate structural shocks. There are many sources of structural shocks and we can address their changing nature by looking at a selected set of structural equation shocks from NiGEM, and we choose consumption, compensation (the main component of personal income) equity price and business investment residuals to see if there are noticeable correlations across countries. Specifications of these equations are as described below ${ }^{12}$.

Table 5 looks at the correlation of these structural shocks across countries between 1991q1 and $1999 \mathrm{q} 4$. We present correlations with the US, which is our main interest in the present context of the transmission from the US to the rest of the G-7. It is evident that the correlations between countries for consumption, business investment and for the

\footnotetext{
${ }^{11}$ Barrell and Dury (2000) discuss these issues. We do not target money, as this is a poor indicator of the underlying target, which we take to be nominal GDP.
} 
compensation variable residuals are low. On the other hand the correlation of the unexplained component of the equity price equation is high over this period except for Japan. It is especially high for France, the UK and Canada vis a vis the US equity market. This suggests that transmission of shocks affecting consumption and to a lesser extent investment tends to occur indirectly via asset prices and does not impact on expenditures or incomes directly.

Table 5: Correlation of structural shocks between US and others

\begin{tabular}{|l|c|c|c|c|}
\hline & Consumption & Compensation & $\begin{array}{l}\text { Business } \\
\text { Investment }\end{array}$ & Equity Prices \\
\hline France & 0.12 & 0.45 & 0.22 & 0.51 \\
\hline Germany & 0.05 & -0.19 & 0.01 & 0.33 \\
\hline Italy & -0.04 & -0.16 & -0.13 & 0.35 \\
\hline UK & -0.50 & 0.24 & 0.12 & 0.65 \\
\hline Japan & -0.07 & -0.31 & -0.23 & -0.10 \\
\hline Canada & 0.12 & 0.11 & 0.28 & 0.55 \\
\hline
\end{tabular}

\section{The 2000-2 bear market}

The interest in equity price simulations is of course heightened by share price trends in recent years. Equity markets fell around 50\% over 2000-2, and it is clear that we witnessed a bear market comparable to that of the early 1970s, as is discussed in Davis (2003). Table 6 derived from Davis (2003) shows that unconditional volatility exhibited a steady rise over 1972-5 with conditional volatility (measured using $\operatorname{GARCH}(1,1)$ estimation) starting higher and rising less. Unconditional and conditional volatility saw a peak in 1998 after which unconditional volatility declined sharply before rising again, while conditional volatility was also on a gradual uptrend albeit never recovering the level of 1998. The differences between the two types of volatility are potentially instructive, given conditional volatility is a closer proxy for expectations and uncertainty. Furthermore, uncertainty proxied by conditional volatility may have an additional effect on consumption over and above wealth effects per se.

In 1972, unconditional volatility was below conditional, suggesting uncertainty in markets at the sustainability of the bull market. Thereafter conditional volatility fell somewhat short of unconditional, especially for the US in 1974 and the UK in 1975 when markets were hit by unpredictable and uncorrelated shocks such as the oil shock as well as expected volatility. Similarly, in 1998 the markets may not have anticipated the level of volatility seen in the Russia/LTCM crisis and hence unconditional was highest, but thereafter as the bear market took hold it was conditional volatility that tended to be higher until 2002 when unconditional was again higher.

\footnotetext{
${ }^{12}$ See also Barrell, Becker, Byrne, Gottschalk Hurst and van Welsum (2004) for a discussion of these equations and of model properties.
} 
Table 6: Average volatility of share prices in the G-7 (per cent)

\begin{tabular}{|c|c|c|c|c|c|c|c|}
\hline & $\begin{array}{c}\text { Standard } \\
\text { deviation }\end{array}$ & $\begin{array}{c}\text { Conditional } \\
\text { volatility }\end{array}$ & Difference & & $\begin{array}{c}\text { Standard } \\
\text { deviation }\end{array}$ & $\begin{array}{c}\text { Conditional } \\
\text { volatility }\end{array}$ & Difference \\
\hline 1972 & 3.68 & 5.23 & -1.55 & 1998 & 7.23 & 6.16 & 1.08 \\
\hline 1973 & 5.57 & 5.47 & 0.10 & 1999 & 4.81 & 5.65 & -0.85 \\
\hline 1974 & 6.85 & 6.50 & 0.34 & 2000 & 5.08 & 5.79 & -0.71 \\
\hline 1975 & 7.13 & 6.98 & 0.16 & 2001 & 5.97 & 5.82 & 0.15 \\
\hline & & & & 2002 & 6.85 & 6.22 & 0.63 \\
\hline
\end{tabular}

Source: $M S C I$

The correlation of domestic share prices with world indices tends to increase in bear markets, reducing the seeming diversification benefits of international investment, and increasing the scope of international spillover effects illustrated in Table 4. Typically, this pattern is thought to reflect common behaviour of institutional investors as well as common fundamentals across the world. Global financial integration has ensured a much higher level of average correlations than in 1975 at the trough of the earlier bear market as Table 7 below from Davis (2003) shows.

Table 7: Correlation of share prices with world indices

\begin{tabular}{|c|c|c|c|c|c|c|c|c|}
\hline & UK & US & Germany & Japan & Canada & France & Italy & $\begin{array}{c}\text { Country } \\
\text { averages }\end{array}$ \\
\hline 1972 & 0.74 & 0.83 & 0.47 & 0.63 & 0.66 & 0.17 & 0.22 & 0.53 \\
\hline 1973 & 0.64 & 0.96 & 0.51 & 0.65 & 0.88 & 0.45 & 0.03 & 0.59 \\
\hline 1974 & 0.59 & 0.95 & 0.39 & 0.09 & 0.78 & 0.80 & 0.50 & 0.59 \\
\hline 1975 & 0.72 & 0.96 & 0.51 & 0.72 & 0.72 & 0.50 & 0.69 & 0.69 \\
\hline & & & & & & & & \\
\hline 1998 & 0.92 & 0.94 & 0.87 & 0.75 & 0.93 & 0.81 & 0.72 & 0.85 \\
\hline 1999 & 0.71 & 0.97 & 0.88 & 0.61 & 0.85 & 0.86 & 0.54 & 0.77 \\
\hline 2000 & 0.78 & 0.96 & 0.44 & 0.54 & 0.81 & 0.66 & 0.22 & 0.63 \\
\hline 2001 & 0.96 & 0.98 & 0.95 & 0.72 & 0.89 & 0.95 & 0.90 & 0.91 \\
\hline 2002 & 0.98 & 0.99 & 0.95 & 0.40 & 0.88 & 0.97 & 0.95 & 0.88 \\
\hline
\end{tabular}

Source: MSCI

Trends in risk premia are one of the key elements in the background to the bear market. There are generally substantially higher returns to saving in equities than other forms of asset holdings, but risk aversion and the need for liquid assets for precautionary and transactions purposes ensures that these holdings never dominate entirely. Theoretical portfolio models often predict a level of risk aversion, which is much lower than that necessary to explain the level of share holdings (for recent evidence see Haliassos and Michaelides, 2000). In particular, the equity premium puzzle suggests that over the past century or so, stocks were not sufficiently riskier than bonds to explain the spread in their returns (Mehra and Prescott, 1985).

Evidence from the 1990s suggested that the risk premium had declined or disappeared, possibly due to the institutionalisation of portfolios (Blanchard 1993), although there may 
also have been a cyclical element in the recent equity bull market, whereby risk premia fell everywhere for reasons that may not have been fully justified. Madsen and Davis (2003), for example, suggest that the response of share prices to productivity shocks was inappropriate, since the impact of the latter on profitability is temporary. The bear market may in this context be viewed partly as a correction of unsustainably low risk premia.

As shown by Jagannathan et al (2000) the risk premium can be proxied by the dividend yield plus expected dividend growth less the real bond yield. IMF (2001) argue that the growth in potential output can be used to proxy expected earnings and dividend growth. Accordingly, Table 8 below shows a measure of the risk premium using a Hodrick Prescott filter on GDP growth to proxy dividend growth ${ }^{13}$. The stylised fact that premia declined in the 1980 s and virtually disappeared in the 1990s is confirmed. The sizeable estimated risk premium in the low-inflation 1960s shows that the decline was not merely a consequence of the impact of disinflation on real bond yields. The peaks of the bull markets in 1972 and 1999 show vast differences in estimated risk premia, albeit in each case generally below the decade-average, underpinning the suggesting of a bubble in 1999, while 1972-5 is better explicable in terms of fundamentals.

Table 8: Estimated risk premia

\begin{tabular}{|l|c|c|c|c|c|}
\hline & Germany & US & UK & France & Canada \\
\hline $1960-69$ & 7.6 & 4.4 & 4.5 & 6.6 & 5.1 \\
\hline $1970-79$ & 5.8 & 7.5 & 9.4 & 11.4 & 7.6 \\
\hline $1980-89$ & 2.3 & 1.8 & 3.2 & 4.1 & 1.1 \\
\hline $1990-94$ & 0.8 & 1.7 & 1.9 & -0.3 & -1.2 \\
\hline $1995-99$ & 0.4 & 0.4 & 1.6 & -0.1 & -0.6 \\
\hline & & & & & \\
\hline Memo: 1972 & 5.9 & 3.5 & 4.3 & 8.9 & 5.3 \\
\hline Memo: 1999 & 0.0 & -0.4 & 1.0 & -0.4 & -0.1 \\
\hline
\end{tabular}

\section{$5 \quad$ Analysing the Impact of Equity Prices}

Using the NiGEM model, we undertook a number of simulations to assess the impact of an equity price decline and the appropriate policy responses. Our major concern was to assess the impact of a US stock market decline on the US and on other economies, with a particular focus on international propagation. This can take place through trade, through the impact of US equity prices on wealth in other countries and through contagion of the equity price fall to other countries' equity markets.

We first undertook a simulation using the NiGEM model of a re-evaluation of future profits in the US equity markets, engineering a fall of 34 percent in the equity price in the US. We 
induce a temporary increase in the perceived equity risk premium, with it slowly declining back to historical levels after 14 years ${ }^{14}$. This large equity price shock in the US spreads to the rest of the world through trade and asset holdings, and is denoted US Premium (USPREM) in the tables in section 5.1. Some of the potential impact of the fall on the US is absorbed by diversified portfolios, and spreads to wealth elsewhere ${ }^{15}$.

Contagion to other countries takes place through equity markets as well as through trade and the impact on the value of foreign holdings of US assets. We can define such contagion in several ways. We note that the experience of 2000-2002, discussed above, is outside the range of correlations observed in the 1990s, and hence using historical correlations of structural residuals to calibrate the expected change in the equity premium elsewhere is not an adequate description of recent events. Accordingly, we simulated a fall in the risk premium of the same magnitude everywhere, except in Japan, and this is noted as All Premia (ALLPREM) in the tables in section 5.1. The Japanese premium fall is $40 \%$ of that in the US, which is consistent with the correlations in the previous section. Equity price falls are lower in other countries than in the US, reflecting in part the greater impact of equity prices on the US economy and hence greater second round effects on equity prices. In particular the greater the impact of the shock on output, the proportionately greater the impact is on future profits, and hence their discounted future value changes more. Similar declines in equity premia generate falls of equity prices of $23 \%$ in France and the Netherlands and 15 to 18 per cent in Germany and Italy as compared to $33 \%$ in the US.

\subsection{Equity Shocks}

The results of our two equity simulations are reported in Table 9. We report on the US, the Euro Area, Germany, France, and Italy and we include the Netherlands because of the scale of its equity markets. It is clear that in all cases the fall in output is largest in the US, reflecting larger wealth effects as well as the impact through the role of $\mathrm{q}$ in determining investment. In the case of the rise in the US premium alone, the results for other countries are driven by lower US demand as well as effects on wealth of US shares in foreign portfolios. It is partly offset by lower bond yields, as discussed below. The simulation ${ }^{16}$ gives an initial $2.5 \%$ fall in US GDP, with much smaller effects elsewhere' as we might expect given the VECM results above. The decline in US equity prices reduces long term interest rates everywhere, albeit by

\footnotetext{
${ }^{13}$ We use the National Institute forecast of output in each of the G7 in the filter to avoid end point problems.

${ }^{14}$ See Barrell (2002) for a discussion of the assumptions.

${ }^{15}$ We undertook a simulation where wealth contagion was "cut off and its effects are noted below. Available as USPREM-default2.txt on NiGEM model v205

${ }^{16}$ Available as USPREM-default1.txt and ALLPREM-default1.txt on NiGEM model v205
} 
more in the US, (see changes in Table 10). This raises bond prices everywhere, offsetting the direct impact of US equities on wealth elsewhere.

Table 9: GDP Effects of Equity Premia and Equity Price Shocks (percentage point difference from baseline level)

\begin{tabular}{|c|c|c|c|c|c|c|c|}
\hline & & Year 1 & Year 2 & Year 3 & Year 4 & Year 5 & Year 6 \\
\hline \multirow[t]{2}{*}{ US } & ALLPREM & -2.54 & -2.72 & -2.58 & -2.21 & -1.71 & -1.14 \\
\hline & USPREM & -2.55 & -2.71 & -2.53 & -2.12 & -1.59 & -1.02 \\
\hline \multirow{3}{*}{$\begin{array}{l}\text { Euro } \\
\text { Area }\end{array}$} & & & & & & & \\
\hline & ALLPREM & -057 & -073 & -0.72 & -0.64 & -055 & -0.44 \\
\hline & USPREM & -0.52 & -0.57 & -0.52 & -0.45 & -0.37 & -0.29 \\
\hline \multirow{2}{*}{ Germany } & ALLPREM & -0.53 & -0.74 & -0.82 & -0.86 & -0.83 & -0.77 \\
\hline & USPREM & -0.49 & -0.63 & -0.68 & -0.71 & -0.69 & -0.64 \\
\hline \multirow[t]{2}{*}{ France } & ALLPREM & -0.63 & -0.71 & -0.67 & -0.62 & -0.60 & -0.58 \\
\hline & USPREM & -0.53 & -0.46 & -0.42 & -0.42 & -0.45 & -0.48 \\
\hline \multirow[t]{2}{*}{ Italy } & ALLPREM & -0.56 & -0.81 & -0.79 & -0.68 & -0.55 & -0.44 \\
\hline & USPREM & -0.50 & -0.62 & -0.48 & -0.28 & -0.09 & 0.05 \\
\hline \multirow[t]{2}{*}{ Neths } & ALLPREM & -0.98 & -0.97 & -0.81 & -0.64 & -0.50 & -0.35 \\
\hline & USPREM & -0.89 & -0.78 & -0.66 & -0.56 & -0.47 & -0.36 \\
\hline
\end{tabular}

Compare these results with Table 3 that takes account of both domestic and US equity price effects in Euro Area country VECMs. The VECM results suggest that the impact of US and European equity prices on the European economies accounts for only 10 to 20 per cent of the variance of output, whilst US equities account for 50 per cent of the variance of output. Hence it is not at all surprising that our concerted equity price shock has around 3 times the effect on the US as it has on the Euro Area countries.

If we restrict contagion via wealth effects (implicitly assuming all US assets are held domestically), the impact on US output is greater, with US output being 0.1 and 0.3 percentage points further below baseline in the second and years of the analysis. Wealth in Canada would be $2 \%$ higher, in the UK it would be $2.5 \%$ higher after 3 years if there were no equity price contagion, and in both countries the output effects would be 0.1 to 0.2 per cent of GDP lower. In the Euro Area wealth would be 2 per cent higher in France, and 3 per cent higher in Germany, reflecting the relative size of their foreign investment stocks, but in both countries the output effects would be smaller by 0.1 per cent less than in the US premium shock. 
Contagion to other equity markets marginally increases the scale of the shock in the US, whilst it increases the impact of the shock by 30 to 40 per cent in the Euro Area countries in the second and third years of the simulation, much in line with the variance decomposition reported above. The increased effects in the US reflects both the trade effects of lower output elsewhere and the impact of lower wealth in the US because of a decline in the value of foreign assets. There are marked disinflationary effects of the shocks, especially in the US where inflation is on average 0.4 per cent below base for the first 5 years of the scenario, although the sharp depreciation of the dollar that we discuss below offsets the effects of lower demand on prices in the first year of the simulation. This is because demand is lower, and hence inflation and output fall below baseline. Disinflationary effects are greater when there is contagion of share price falls. In response, the monetary authority is expected to cut nominal rates now and in the future. Reflecting these patterns, Table 10 shows that US nominal and real long rates also fall in each simulation, along with the effective exchange rate. All these changes help absorb the shock in the US, although the fall in the US effective exchange rate propagates the shock. Table 10 also gives the changes in exchange rates under the set of shocks. In general, currencies other than the US dollar appreciate, and propagation takes place through competitiveness effects in addition to the demand and wealth effects. However, the appreciation is marginally less when the equity price shock propagates to other countries, and this helps absorb some the extra shock suffered outside of the US.

\section{Table 10: US Effective Exchange Rate and Long Rates}

percentage points difference from baseline in first year

\begin{tabular}{|l|l|l|l|l|}
\hline & $\begin{array}{l}\text { Long } \\
\text { Rate }\end{array}$ & $\begin{array}{l}\text { Long } \\
\text { Real } \\
\text { Rate }\end{array}$ & $\begin{array}{l}\text { dollar } \\
\text { euro rate }\end{array}$ & $\begin{array}{l}\text { dollar } \\
\text { effective } \\
\text { rate }\end{array}$ \\
\hline & & & & \\
\hline ALLPREM & -2.04 & -1.60 & -7.64 & -4.48 \\
\hline & & & & \\
\hline USPREM & -1.92 & -1.52 & -7.81 & -4.51 \\
\hline
\end{tabular}

It is useful to trace the monetary reaction in the model and in the world in more detail. We have undertaken a simulation with equity-based wealth permanently lower as a ratio of GDP and hence in the simulation saving has to rise to achieve the equilibrium wealth-income ratio embedded in the equation for consumption. This changes the saving and investment balance and ceteris paribus, investment will be less than saving. If this happens, nominal rates would be cut in every period that inflation and output would be below target. Nominal rates will be cut until demand reaches capacity and inflation settles on target, and this requires that the real interest rate is lower period by period than it is on our baseline. Hence the long real rate is 
also lower. Long real rates fall elsewhere, but not by as much. Euro Area rates fall by $40 \%$ of the US fall, for instance. Euro Area inflation rates fall by 0.3 percentage points in the first year and 0.2 percentage points over the next four years of the all equity price simulation. The effects are marginally less in the US only equity price fall simulation, moderated by the smaller appreciations associated with equity price contagion.

\subsection{Policy Responses to the Shock}

The impact of the shock is not given solely by the behavioural relationships of the private sector, asset price dynamics and the pattern of trade and asset holdings, but also depends on the policy response of the authorities. The VECM results above represent the average policy response we have seen over the last 30 years, and hence neither take account of improvements we may have seen in macro economic management, not do they allow us to look at the effects of short term policy innovations. As noted, NiGEM has inbuilt rules which target inflation in the case of monetary policy and seek budget balance over 5 years in the case of fiscal policy. The monetary policy rules use the short-term interest rate as an instrument, and long-term interest rates are determined by the market in the light of their expectations of future shortterm rates given their knowledge of the feedback rule and the structure of the economy.

\section{Changing the Monetary Feedback in the US}

It is useful to analyse the impact of easier monetary policy via raising the response to inflation of the monetary authorities in the monetary rules. We can change the monetary response in the US, either by doubling the feedback on inflation by implementing a Taylor Rule ${ }^{17}$ in that country, or by increasing the feedback coefficient on the output gap within a Taylor Rule, and the results are presented in Table 11.

\section{Table 11: Impacts on Output of a Larger Monetary Reaction in the US}

(Percentage difference in GDP from US Equity Premium results)

\begin{tabular}{|l|r|r|r|}
\hline & Year 1 & \multicolumn{1}{l|}{ Year 2 } & \multicolumn{1}{l|}{ Year 3 } \\
\hline Euro Area -US Taylor Rule & 0.16 & 0.14 & 0.04 \\
\hline (\% of shock) & -31.27 & -25.21 & -8.36 \\
\hline Euro Area - US Double output feedback & 0.16 & 0.14 & 0.06 \\
\hline (\% of shock) & -31.16 & -25.51 & -11.12 \\
\hline US- US Taylor Rule & 0.15 & 0.19 & 0.14 \\
\hline (\% of shock) & -6.05 & -7.18 & -5.65 \\
\hline US - US Double Output feedback & 0.36 & 0.42 & 0.30 \\
\hline (\% of shock) & -14.03 & -15.49 & -12.00 \\
\hline
\end{tabular}

The Taylor Rule has twice the feedback on inflation as compared to our default, and hence the deflationary shock in the US leads to a larger fall in interest rates and hence to a smaller fall in

${ }^{17}$ Available as USPREM-USTR-default.txt and USPREM-USTR-BIGIG2.txt on NiGEM model v205 
output. Short rates fall by 1.2 percentage points in our base simulation, by 1.5 in our greater inflation response simulation, and by 2.0 in our additional greater output response simulation. The associated fall in long rates is the same in the last two simulations, and is twice the size of the base case fall. This action in the US removes about 7 per cent of the shock, with the same absolute impact on the Euro Area (where the shock is smaller). Doubling the feedback coefficient on output in the US Taylor Rule is especially beneficial for the US, where a further 8 per cent of the initial shock is removed, but there is no additional gain to the Euro Area form this change as it has no impact on world long term interest rates.

\section{Monetary Responses outside the US}

We can also focus on the monetary response in the rest of the world, and we assume in the external extra monetary response scenario that the coefficient on inflation in the feedback rule used by all central banks outside the US is doubled ${ }^{18}$. Given the disinflationary impact of the equity price shock, interest rates are cut further. Table 12 shows that the impact on GDP of the US equity price shock in the Euro Area can be attenuated by a monetary response. Doubling the feedback coefficient removes about 20 per cent of the impact on the Euro Area of an equity price shock in the US. The stronger feedback in response to lower inflation reduces interest rates by 0.8 percentage points in the first year, rather than 0.6 percentage points as in our base case. However, there is little impact on ling term interest rates, and hence the effects are smaller in the bank based German economy than in the slightly more market based economies of Italy and particularly France and the Netherlands.

\section{Table 12: Impacts on Output of a Larger Monetary Reaction outside the US}

(Percentage difference in GDP from US Equity Premium results)

\begin{tabular}{|l|r|r|r|r|}
\hline & Year 1 & Year 2 & Year 3 & Year 4 \\
\hline US & 0.00 & 0.00 & 0.00 & 0.00 \\
\hline (\% of shock) & 0.02 & -0.04 & -0.05 & 0.14 \\
\hline Euro Area & 0.03 & 0.07 & 0.08 & 0.08 \\
\hline (\% of shock) & -6.32 & -12.26 & -16.21 & -18.09 \\
\hline Germany & 0.03 & 0.07 & 0.09 & 0.08 \\
\hline (\% of shock) & -6.96 & -11.58 & -12.87 & -11.61 \\
\hline France & 0.04 & 0.07 & 0.08 & 0.07 \\
\hline (\% of shock) & -6.79 & -14.66 & -18.81 & -17.88 \\
\hline Italy & 0.03 & 0.06 & 0.08 & 0.08 \\
\hline (\% of shock) & -5.41 & -10.30 & -16.82 & -27.14 \\
\hline Neths & 0.05 & 0.09 & 0.10 & 0.09 \\
\hline (\% of shock) & -5.40 & -11.20 & -14.66 & -15.28 \\
\hline
\end{tabular}

\footnotetext{
${ }^{18}$ We used $\mathrm{r}=0.75$ (inflation - target) +.5 (Nominal output - target) and then we raised 0.75 to 1.5 . Available as USPREM-DEFAULT1+FEED.txt on NiGEM model v205
} 


\section{Fiscal Feedbacks in the US}

The US does have the possibility of loosening its fiscal stance. Our standard mode of operation has a fiscal feedback rule in place from the start of the run, and this will induce a rise in direct taxes in response to the reductions in revenues and increases in spending that come from the reduction in demand and output that follow from the equity shock. There are various ways to change the fiscal response in the US, but the simplest is to assume that the fiscal feedback rule does not operate for the first five years of the scenario ${ }^{19}$ (denoted "turning solvency off'). This will induce an increase in the budget deficit, and after 4 years the US debt stock would be more than 1 percent of GDP higher than it would otherwise have been. The real long term interest rate (and the nominal long rate) is 0.12 higher than it would otherwise have been in response to an increase in the US deficit of 0.33 per cent of GDP on average over 4 years. It would be possible to simulate a direct fiscal response to the decline in equity prices, and indeed we may have seen that in the US, where the budget moved from a surplus of around 1.5 per cent of GDP in 2000 to a deficit of 31/4 per cent of GDP in 2002.

The impact of the fiscal loosening on GDP is given in Table 13. Clearly, the US is the main beneficiary, and output would be 0.25 percentage points higher after 3 years than in the base US premium shock by the third year of our simulations. However, the direct effects of this passive fiscal response are slow to come through, as they operate through a lower tax take. Some of the potential expansionary effects will be offset by higher real interest rates in the US, and as financial markets are presumed to be forward looking, long real rates jump up, and hence output effects are slightly larger in the first year than in our base case. This contractionary fiscal expansion only lasts for one year, however. Elsewhere the rise in long term real rates partly offsets the demand effects, and output is only marginally above that in the base case simulation in the Euro Area.

\section{Table 13: Impact on Output of Turning Solvency off in the US}

(Percentage difference in GDP from US Equity Premium results)

\begin{tabular}{|l|r|r|r|r|}
\hline & \multicolumn{1}{|c|}{ Year 1 } & \multicolumn{1}{|c|}{ Year 2 } & \multicolumn{1}{|c|}{ Year 3 } & Year 4 \\
\hline Euro Area & 0.00 & 0.02 & 0.04 & 0.06 \\
\hline $\begin{array}{l}\text { (\% of } \\
\text { shock) }\end{array}$ & 0.25 & -3.27 & -8.50 & -12.75 \\
\hline US & -0.05 & 0.06 & 0.24 & 0.31 \\
\hline $\begin{array}{l}\text { (\% of } \\
\text { shock) }\end{array}$ & 2.06 & -2.24 & -9.37 & -14.59 \\
\hline
\end{tabular}

${ }^{19}$ Available as USPREM-default1-NOSP.txt on NiGEM model v205 


\section{Conclusions}

Equity prices falls over 2000-2 were comparable to the bear market of the mid 1970s, although evidence of a bubble is much stronger in recent years (given the low level of the risk premium) and correlations between equity markets have been much stronger. Based on estimated relationships, falls in equity prices of the scale observed can have significant recessionary effects on the world economy. In our VECM results we show that the contribution of equity prices to a variance decomposition of output is around 3 times greater in the US, at 50 per cent, than in the larger Euro Area economies. Composition of wealth, openness and trade patterns are among the key factors which influence the scope of output responses internationally. For the US in particular, the reliance of firms on market based finance helps explain why equity prices have a much more sizeable impact on prices than they do in Europe. Variance decompositions in VECM studies can only evaluate the 'average' policy response in the sample period, however, and we need to use structural models to explain how policy may mitigate the effects of shocks.

We undertake simulations on our model NiGEM and show that falls in equity prices have around three times greater an impact in the US than they do in the Euro Area, much as we would expect from the VECMs. However, the scale of impacts is not immutable. Monetary easing can help absorb such a shock. Fiscal policy loosening can also help offset the effects of a collapse in equity prices, but it will mean higher long term real interest rates and hence it moderates one of the automatic shock absorbers provided by the market mechanism. In our experiments we show that a monetary easing either in the US or the Euro Area associated with a change in feed back parameters can remove up to a fifth of impact of the initial shock in the area where the easing takes place. A loosening of the solvency constraint also allows 10 per cent of the shock to be absorbed in the country where loosening takes place by increasing the debt stock. Clearly in both cases monetary and fiscal actions could be stronger, but if the US were to respond to an equity market shock by reducing the emphasis on inflation in its

policy setting and loosening fiscal constraints, it could remove up to a third of the impact of the shock on the economy. We would conclude both that active policy in response to equity price falls is wise and that structural models are a useful part of the policy analysis toolkit. 


\section{References}

Allen Franklin., Chui, Michael., and Maddeloni, Angela, (2004) 'Financial Systems in Europe, the US and Asia' Oxford Review of Economic Policy vol 20 pp 490 - 508

Ashworth Paul and Davis E Philip (2001). 'Some evidence on financial factors in the determination of aggregate business investment for the G7 countries' Discussion Paper No 187, National Institute of Economic and Social Research

Barrell Ray (2002), "Equity markets, block realignments and the UK exchange rate", National Institute Economic Review, 181 (July), 38-43

Barrell, Ray, Becker, Bettina, Byrne, Joe, Gottschalk. Sylvia, Hurst, Ian., and van Welsum, Desiree, (2004) 'Macroeconomic Policy in Europe: Experiments with monetary responses and fiscal impulses' Economic Modelling, 21, 977-1031

Barrell, R., Byrne J., and Dury K., (2003) 'The implications of diversity in consumption behaviour for the choice of monetary policy rules in Europe' Economic Modelling, 20, 275-299

Barrell Ray and Davis E Philip (2004a), "Consumption, financial and real wealth effects in the G5", Discussion Paper No. 232, NIESR, London

Barrell Ray and Davis E Philip (2004b), "Financial liberalisation, consumption and wealth effects in 7 OECD countries", Discussion Paper No. 247, NIESR, London

Barrell Ray and Davis E Philip (2005), "Equity prices and the real economy - a Vector Error Correction approach", paper presented at the FINPROP conference, DIW, Berlin, July 2005

Barrell, Ray, and Dury, Karen, (2000) 'An Evaluation of Monetary Targeting Regimes' National Institute Economic Review No. 174 October 2000

Barrell, Ray., and Dury, Karen, (2003) 'Asymmetric labour markets in a converging Europe: Do differences matter? National Institute Economic Review January

Blanchard, Olivier J. 1993, "The Vanishing Equity Premium", in ed R O'Brien, Finance and the International Economy 7, Oxford University Press.

Bond, S., Elston, J.A., Mairesse, J., and Mulkay, B., (2003) 'Financial Factors and investment in Belgium, France, Germany and the United Kingdom: a comparison using company panel data.' Review of Economics and Statistics vol 85 pp 153-165

Byrne Joe and Davis E Philip (2003a), Disaggregate Wealth and aggregate consumption: an investigation of empirical relationships for the G7", Oxford Bulletin of Economics and Statistics, 65, 1-23

Byrne Joe and Davis E Philip (2003b), "Financial structure", Cambridge University Press

Davis E Philip (2003), “Comparing bear markets - 1973 and 2000”, National Institute Economic Review, 183, 70-81

Davis, M.A. and Palumbo, M.G. (2001). A Primer on the Economics and Time Series Econometrics of Wealth Effects, Finance and Economics Discussion Paper, Federal Reserve Board Washington.

Gilchrist, S., Himmelberg, C., and Huberman, G., (2004) 'Do stock Price Bubbles Influence Corporate Investment?' NBER Working Paper 10537

Haliassos, Michael and Michaelides, Alexander (2000) Calibration and computation of household portfolio models. In Guiso, Luigi. Haliassos, Michael. and Jappelli, Tullio (eds.) Household Portfolio. MIT. 
Hubbard, R., (1998) 'Capital Market imperfections and Investment' Journal of Economic Literature vol 36 pp193-225

International Monetary Fund (IMF), (2001), "Asset Prices and the Business Cycle," in World Economic Outlook, April, 101-149.

International Monetary Fund (IMF), (2003), "When bubbles burst," in World Economic Outlook, April, 61-94.

Jagannathan R, McGrattan Ellen and Scherbina Anna (2000), "The declining US risk premium", Federal Reserve Bank of Minneapolis Quarterly Review, 24/4, 3-19

Johansen, Soren., (1995) 'Likelihood-Based Inference in Cointegrated Vector Autoregressive Models' Oxford University Press

Lettau, Martin and S. Ludvigsen (2001) "Consumption, aggregate wealth and expected stock returns." Journal of Finance

Ludvigsen, Sydney and Steindel, Charles (1999). How Important is the Stock Market Effect on Consumption? Economic Policy Review, Federal Reserve Bank of New York, July.

Madsen Jakob and Davis E Philip (2003), "Equity prices, productivity growth and the "New Economy"”, forthcoming, Economic Journal

Mehra, Rajnish and Prescott, Edward C. (1985). The equity premium: A puzzle. Journal of Monetary Economics 15, 145-161.

Pesaran, M.Hashem, Scheurmann, T., and Weiner, S., (2004) 'Modelling regional interdependencies using a global error-correcting macroeconometric model' Journal of Business and Economic Statistics vol. 22 pp 129-162

Pesaran, M.Hashem, Scheurmann, T., Treutler, BJ., and Weiner, S., (2005) 'Macroeconomic dynamics and credit risk, a global perspective' Journal of Money Credit and Banking forthcoming 